\title{
Pengaruh Kualitas Pelayanan Terhadap Kepuasan Pasien (Studi Kasus di Puskesmas Kecamatan Depati VII Kabupaten Kerinci)
}

\author{
Edia Satria \\ Sekolah Tinggi Ilmu Ekonomi Sakti Alam Kerinci \\ Correspondence email: ediasatria85@gmail.com
}

\begin{abstract}
This study aims to determine 1) The extent to which the influence of the service quality on patient satisfaction of Puskesmas Kecamatan Depati VII Kabupaten Kerinci? 2) The extent to which the influence of the service quality on patient satisfaction of Puskesmas Kecamatan Depati VII Kabupaten Kerinci either directly or indirectly? The Population in this study is patient of Puskesmas Kecamatan VII Kabupaten Kerinci period of 2017 totaling 7622 patients. Furthermore, by using the formula slovin, then obtained sample size of 75 patients with sampling accidental sampling technique. Data analysis tool used is the analysis of the path at an alpha level of 0.05. Based on the results of the study showed that: service quality positive and significant effect on patient satisfaction. Both directly and indirectly the quality of service has a positive and significant effect on patient satisfaction.
\end{abstract}

Keywords: service quality patient satisfaction

\section{Pendahuluan}

Pada saat ini masalah kesehatan sudah menjadi kebutuhan yang utama bagi masyarakat. Kebutuhan yang dimaksud adalah kebutuhan untuk mendapatkan pelayanan kesehatan yang prima. Seiring dengan meningkatnya taraf kehidupan masyarakat, maka semakin meningkat pula tuntutan masyarakat akan nilai-nilai kesehatan. Irawan (2008) kepuasan adalah perasaan senang atau kecewa dari seseorang yang mendapatkan kesan dari perbandingan hasil pelayanan kinerja dengan harapan-harapannya. Sedangkan Kotler (2003) mendefinisikan kepuasan sebagai perasaan senang atau kecewa seseorang yang dialami setelah membandingkan antara persepsi kinerja atau hasil suatu produk dengan harapanharapannya. Goetsch Davis, dalam Yamit, (2005) kualitas merupakan suatu kondisi dinamis yang berhubungan dengan produk, jasa, manusia, proses, dan lingkungan yang memenuhi atau melebihi harapan. Pendekatan yang digunakan Goetsch Davis ini menegaskan bahwa kualitas bukan hanya menekankan pada aspek hasil akhir, yaitu produk dan jasa tetapi juga menyangkut kualitas manusia, kualitas lingkungan. Sangatlah mustahil menghasilkan produk dan jasa yang berkualitas tanpa melalui manusia dan proses yang berkualitas. Pelayanan adalah proses pemenuhan kebutuhan melelui aktivitas orang lain secara langsung (Moenir, 1992).

\section{Metode}

Penelitian ini dilakukan untuk menguji hipotesa yang diajukan dengan menggunakan metode penelitian yang telah dirancang sesuai dengan variabel variabel yang akan diteliti agar mendapatkan hasil penelitian yang akurat. Maka diperlukan dukungan data dari objek penelitian. Penulis jadikan objek dalam penelitian ini adalah Puskesmas Depati VII. Jenis data yang digunakan dalam penelitian ini adalah data primer yaitu data kualitatif yang diperoleh dari hasil wawancara dan kuisioner. Dalam penelitian ini jenis data yang digunakan adalah data primer dan data sekunder. Data primer merupakan data penelitian yang diperoleh secara langsung dari sumber asli (tidak melalui perantara). Data primer secara khusus dikumpulkan oleh peneliti untuk menjawab penelitian (Indriantoro dan Supomo,1999). Data sekunder menurut sugiyono (2009). Data sekunder merupakan sumber data yang diperoleh dengan cara membaca,mempelajari dan memahami melalui media lain yang bersumber dari literatur,buku-buku,serta dokumen perusahaan. Data yang digunakan dalam penelitian ini adalah data primer dan data sekunder dimana data primer didata yang di dapat dari tempat peneltian yaitu pasien pukesmas Depati VII Kabupaten Kerinci dan data sekunder di dapat dari kantor pukesmas Depati VII Kabupaten Kerinci.

Teknik pengumpulan data yang digunakan dalam penelitian ini berupa studi keputusan (library research) yakni dengan pengambilan data yang dilakukan dengan membaca buku-buku, literatur-literatur serta tulisan ilmiah yang berkaitan dengan masalah yang dibahas. Penelitian lapangan (Field Research) yaitu pengumpulan data untuk memperoleh data primer dengan cara melakukan penelitian langsung di lapangan yiatu langsung kepada pasien pukesmas Depati VII Kabupaten Kerinci. Penelitian yang dilakukan ini dapat digolongkan sebagai penelitian yang menggunakan metode analisis deskriptif kuantitatif dan deskriptif kualitatif. Metode analisis deskriptif kuantitatif yakni analisa yang berbentuk angka-angka dalam hal ini dipakai analisis statistik. Analisa statistik adalah suatu metode guna memperoleh, mengolah dan menyajikan, menganalisa serta menginterprestasikan data yang berwujud angka-angka. Sedangkan metode analisis deskriptif kualitatif merupakan bentuk analisa dengan kata kata bukan berbentuk angka melainkan berbentuk analisa secara penalaran bersumber dari penelitian terdahulu dan leteratur- 
Edia Satria, Pengaruh Kualitas Pelayanan Terhadap Kepuasan Pasien (Studi Kasus di Puskesmas Kecamatan Depati VII Kabupaten Kerinci)

literatur yang relevan. Alat analisis data dilaksanakan dengan smelakukan perhitungan-perhitungan yang relevan terhadap masalah yang diteliti. Untuk mengolah data yang telah dikumpulkan dari hasil penelitian, penulis menggunakan metode sebagai berikut.

\section{Regresi Linier Sederhana}

Analisis regresi linier sederhana digunakan untuk mengetahui hubungan sebab akibat dengan menentukan nilai Y (sebagai variabel dependen) dan untuk menaksir nilai-nilai yang berhubungan dengan $\mathrm{X}$ (sebagai variabel independen), dengan menggunakan rumus statistik atau model matematis berikut ini : $Y=\alpha+\beta X$

\section{Koefisien Determinasi (KD)}

Koefisien determinasi (R2) pada intinya mengukur seberapa jauh kemampuan model dalam menerangkan variasi variabel independen. Nilai koefisien determinasi adalah antara nol dan satu. Rumus :

$\mathrm{Kd}=\mathrm{r}^{2} \mathrm{X} 100 \%$

\section{Uji F}

Uji pengaruh simultan digunakan untuk mengetahui apakah variabel independen secara simultan mempengaruhi variabel independen (Ghozali, 2006). Rumus: $F=R^{2} / K\left(1-R^{2}\right)(N-K-1)$

\section{Hasil}

Tabel 1

Analisis Regresi Linear Sederhana Pengaruh Kualitas Pelayanan Terhadap Kepuasan Pasien Puskesmas Depati VII Kabupaten Kerinci

\begin{tabular}{|ll|r|r|r|r|r|}
\hline \multirow{2}{*}{ Model } & \multicolumn{2}{|c|}{ Unstandardized Coefficients } & Standardized Coefficients & \multirow{2}{*}{ S } & \multirow{2}{*}{ Sig. } \\
\cline { 3 - 7 } & \multicolumn{2}{|c|}{ B } & Std. Error & Beta & 4,830 &, 000 \\
& (Constant) & 25,824 & 5,346 & &, 000 \\
\hline
\end{tabular}

Sumber: data olahan

Berdasarkan tabel 1 diketahui hasil perhitungan uji t kualitas pelayanan (X) terhadap Kepuasan Pasien (Y) diperoleh persamaan garis regresi adalah $\mathrm{Y}=4,830+4,275(\mathrm{X})$. Hal ini dapat diartikan bahwa besar pengaruh variabel kualitas pelayanan terhadap kepuasan pasien adalah sebesar thitung 4,275 dengan signifikan t sebesar 1.66571 dengan menggunakan signifikansi 0,05 . Karna $t_{\text {hitung }}$ besar dari $t_{\text {tabel }}$ ini berarti hubungan pengaruh kualitas pelayanan terhadap kepuasan pasien Puskesmas depati VII Kabupaten Kerinci periode 2017 adalah positif signifikan atau dapat diartikan berpengaruh. Dengan arti lain bahwa kualitas pelayanan yang diberikan oleh pukesmas Depati VII Kabupaten Kerinci membuat pasien merasa puas akan pelayanan yang diberikan membuat para pasien selalu mengunjungi pukesmas Depati VII apabila mengalami sakit.

Tabel 2

Besar Pengaruh Kualitas Pelayanan (X) Terhadap Kepuasan Pasien (Y)

\begin{tabular}{|l|l|r|r|r|}
\hline \multicolumn{1}{|c|}{ Model } & R & R Square & Adjusted R Square & Std. Error of the Estimate \\
\hline 1 &, 447 &, 200 &, 189 & 9,19008 \\
\hline
\end{tabular}

Sumber: data olahan

Berdasarkan Tabel 2 terdapat $\mathrm{R}$ square (determinasi) adalah 0,447 adalah pengkuadratan dari koefisien korelasi 0,447 . R square dapat disebut koefisien determinasi yang dalam hal ini 44,70\% kontribusi variabel kualitas pelayanan terhadap kepuasan pasien pada Puskesmas Depati VII Kabupaten Kerinci. Sedangkan sisanya sebesar $55,3 \%$ dapat dijelaskan dengan sebab sebab lain yang tidak di teliti pada penelitian ini atau dipengruhi oleh faktorfaktor lain.

\section{Simpulan}

Berasarkan hasil analisis data dan pembahasan hasil penelitian maka dapat disimpulkan sebagai berikut.

1. Kualitas pelayanan $(\mathrm{X})$ terhadap kepuasan pasien $(\mathrm{Y})$ diperoleh $\mathrm{t}_{\text {hitung }}(4,275)>\mathrm{t}_{\text {tabel }}(1.66571)$ dan signifikan $<$ $0,05(0,000<0,05)$. Dari hasil diatas dinyatakan bahwa kualitas pelayanan berpengaruh positif signifikan terhadap kepuasan pasien Puskesmas Depati VII Kabupaten Kerinci. 
Edia Satria, Pengaruh Kualitas Pelayanan Terhadap Kepuasan Pasien (Studi Kasus di Puskesmas Kecamatan Depati VII Kabupaten Kerinci)

2. Besar pengaruh kualitas pelayanan (X) terhadap kepuasan pasien (Y) pada pasien Puskesmas Depati VII Kabupaten Kerinci periode 2017 adalah sebesar 44,70\% sedangkan sisanya 55,3\% dapat dijelaskan oleh variabel-variabel lain di luar variabel penelitian.

\section{Daftar Pustaka}

Andrianyansah \& Sunardji Daromi, 2005, Analisis Kepuasan Pasien Terhadap Kualitas Pelayanan Kesehatan Di Rumah Sakit Umum Kabupaten Belitung, SINERGI

Ardian Adhiatma, 2001. Analisis Kepuasan Konsumen Terhadap Kualitas Pelayanan Jasa Kesehatan Di Rumah Sakit Ibu dan Anak di Semarang, Vol.2, No.2, 67-76.

Cooper, Donald R dan C William Emort. 1999. Metode Penelitian Bisnis (Jilid 1 Edisi Kelima). Jakarta: Penerbit Erlangga.

Malayu. S. P. Hasibuan, Pengorganisasian.

Ghozali, Imam. 2001. Aplikasi Analisis Multivariate dengan Program SPSS. Semarang: Badan Penerbit Universitas Diponegoro.

Guntur SW. 2006. Analisis Service Quality terhadap Kepuasan Pelanggan (Studi PDAM Kota Surakarta, Tesis. Surakarta: Program Magister Manajemen

Henri. 2003. Analisis Pengaruh Kualitas Pelayanan terhadap Kepuasan Pasien Rawat Inap di Rumah Sakit PKU Muhammadiyah Yogyakarta, Tesis. Yogjakarta: Program Pascasarjana Universitas Islam Indonesia.

Rainier Hendrik Sitaniapessy \& Harry A.P. Sitaniapessy, 2006, Kualitas Jasa Pelayanan Dalam Upaya Peningkatan Kepuasan Konsumen, Jurnal Ekonomi \& Bisnis No.1, jilid 11.

Kotler, Philip. 1999. Manajemen Pemasaran di Indonesia (Alih Bahasa A.B. Susanto). Jakarta: PT Salemba Empat.

Kotler, Philip. 1999. Manajemen Pemasaran (Edisi Milennium). Jakarta: PT

Kuncoro, Mudrajad. 2001. Metode Kuantitatif: Teori dan Aplikasi untuk Bisnis dan Ekonomi (Edisi I). Yogjakarta: AMP YKPN.

Rainier Hendrik Sitaniapessy \& Harry A.P. Sitaniapessy, 2006, Kualitas Jasa Pelayanan Dalam Upaya Peningkatan Kepuasan Konsumen, Jurnal Ekonomi \& Bisnis No.1, jilid 11.

Rambat Lupiyoadi \& A. Hamdani, 2006, Manajemen Pemasaran Jasa, 2 ed, Salemba Empat : Jakarta.

Thomas H Nelson. Manajemen. 